\title{
IVAIRAUS INTENSYVUMO AEROBINIO PRIEŠKRŪVIO POVEIKIS ŠIRDIES SUSITRAUKIMŲ DAŽNIO KAITAI KARTOTINIO NUOSEKLIAI DIDINAMO KRŪVIO METU
}

\author{
Loreta Dubininkaitė, Arvydas Stasiulis, Neringa Baranauskienė
} Lietuvos kūno kultūros akademija, Kaunas, Lietuva

\begin{abstract}
Loreta Dubininkaitė. Biologijos magistrè. Lietuvos kūno kultūros akademijos Taikomosios fiziologijos ir sveikatos ugdymo katedros asistentė. Mokslinių tyrimų kryptis - aerobinio pajègumo rodiklių kaitos specifiškumas dèl trumpalaikio ir ilgalaikio fizinio krūvio poveikio.
\end{abstract}

\section{SANTRAUKA}

Tyrimo tikslas - nustatyti Ł̇vairaus intensyvumo aerobinio prieškrūvio poveiki širdies susitraukimu dažnio (ŠSD) kaitai kartotinio nuosekliai didinamo krūvio (KDK) metu.

Aštuoni fiziškai aktyvūs studentai (amžius - 22,5 (2,6) m., ūgis - 1,8 (0,3) cm, svoris - 69,6 (9,8) kg) buvo testuojami tris kartus. Viena karta tiriamieji „,Monark $834 E^{\prime \prime}$ (Švedija) veloergometru atliko KDK testa, kurio metu buvo palaikomas pastovus mynimo dažnumas $70 \mathrm{k}$. / min, pirmo krūvio dydis $-50 \mathrm{~W}$ ir toliau didinamas po $25 \mathrm{~W}$. Krūvio trukmé $-3 \mathrm{~min}$, poilsio tarp krūviu — keturios. Atliekant KDK testa, pulso matuokliu „Polar S810“ (Suomija) 5 s intervalais buvo registruojamas ŠSD. Kai tiriamojo ŠSD pasiekdavo 80\% maksimalaus, apskaičiuoto pagal jo amžiu (220 - amžius), testas būdavo nutraukiamas. Individualus tiriamujų laktato slenkstis (LaS) netiesioginiu būdu buvo nustatytas pagal ŠSD absoliučias reikšmes atsigavimo metu atliekant KDK testa (Stasiulis, 1997). Dar du kartus skirtingomis dienomis tiriamieji ši testa atliko praejus penkioms poilsio minutems po 30 min trukmés vidutinio arba didelio intensyvumo aerobinio prieškrūvio (atitinkamai VAP arba DAP). VAP dydis buvo $25 \mathrm{~W}$ mažesnis už individualu tiriamojo LaS, DAP - $25 \mathrm{~W}$ didesnis už LaS. Norint nustatyti tiriamuju laktato koncentracija (La), kapiliarinio kraujo méginiai iš rankos piršto buvo imami tyrimo pradžioje, taip pat atliekant prieškrūvi 5-a, 10-a, 20-a ir 30-a min. Laktato koncentracija kraujyje buvo nustatoma naudojant modifikuota analizatoriu „Eksan-G“ (Kulis et al., 1988). ŠSD kaita buvo analizuojama „,Microcal Origin" programa taikant monoeksponentinio trendo lygti. Skirtingomis testavimo salygomis gautu rodikliu vidurkiai buvo palyginami taikant neparametrini Wilcoxon testa priklausomoms imtims.

Rezultatai rodo, kad tiriamuju laktato koncentracija kraujyje po 30 min DAP buvo reikšmingai padidejusi iki 2,85 $(0,64) \mathrm{mmol} / \mathrm{l}(\mathrm{p}<0,05)$, tačiau po tokios pat trukmés VAP nepakito $(1,08(0,81) \mathrm{mmol} / l ; p>0,05)$. Absoliučios ŠSD reikšmès trečios darbo minutès pabaigoje atliekant $K D K$ po VAP buvo reikšmingai didesnès $(p<0,05)$ visais krūvio atvejais, išskyrus tada, kai intensyvumas buvo $50 \mathrm{~W}$ didesnis už LaS. Ketvirta atsigavimo minutę šis rodiklis taip pat reikšmingai padidejo $(p<0,05)$, kai intensyvumas buvo iki arba lygus LaS. Po DAP absoliučios ŠSD reikšmés buvo reikšmingai didesnés viso KDK testo metu $(p<0,05)$. Atlikus ŠSD kaitos monoeksponentinio trendo rodikliu analize nustatyta, kad nei po vidutinio, nei po didelio aerobinio prieškrūvio šio rodiklio kaitos dydžiai (amplitude ir laiko konstanta) nepakito $(p>0,05)$. Taigi ir lengvesnis, ir sunkesnis už laktato slenksti (atitinkamai — vidutinio ir didelio intensyvumo) 30 min trukmès aerobinis prieškrūvis veikia absoliučias ŠSD reikšmes (jas padidina), bet nekeičia ŠSD kaitos santykinio greičio ir pokyčio dydžio atliekant kartotinì (3 min darbo ir 4 min poilsio) nuosekliai didinama krūvi.

Raktažodžiai: širdies susitraukimu dažnis, prieškrūvis, laktatas, darbo intensyvumas.

\section{IVADAS}

$\mathrm{F}$ izinio krūvio metu žmogaus organizmas retai dirba pastovaus metabolizmo sąlygomis. Griaučiu raumenų darbo pradžia, kurios metu vyksta organizmo isidirbimas, ir darbo pabaiga, kai prasideda atsigavimo procesai, taip pat intensyvumo kaita dirbant yra susiję su poreikiu greitai pakeisti metabolizmo intensyvuma. Nustatyta, kad deguonies suvartojimo bei su juo susijusio širdies susitraukimų dažnio (ŠSD) kaita isidirbimo ir atsigavimo metu rodo žmogaus aero- bini pajègumą ir jo adaptacijos prie fizinio krūvio galimybes (Jones, Carter, 2000). Greitis, kuriuo aerobinè ATP resintezè griaučių raumenyse prisitaiko prie naujo energijos poreikio, veikia tokias greitosios adaptacijos prie fizinio krūvio savybes kaip isidirbimas, nuovargis ir atsigavimas. Greitesnè aerobinès oksidacijos adaptacija sumažina ląstelès ir organų homeostazès pokyčius darbo pradžioje ar pasikeitus intensyvumui (Grassi, 2001). 
Šiuo metu dar neaišku, kiek deguonies suvartojimo kaita priklauso nuo deguonies tiekimo raumenims ir kiek nuo deguonies suvartojimo raumenyse, todèl per pastaruosius 20 metų tai labai kruopščiai tyrinejjama (Tschakovsky, Hughson, 1999). Jeigu ši kaita priklausytų nuo deguonies tiekimo, tai ji pagreitinus turètų spartèti ir deguonies suvartojimo kaita. Manoma, kad paveikti deguonies tiekimą dirbančiam raumeniui galètu prieš tai atliktas prieškrūvis. Tokiomis sąlygomis pakitusi deguonies tiekimą i raumenis galètų rodyti ŠSD pokyčiai prieš darbą ir jo pradžioje. Manoma, kad ŠSD fizinio darbo ir atsigavimo metu rodo deguonies pernešimo į raumenis kaita.

Vienodo intensyvumo fizinio darbo pradžioje ir iš karto po jo ŠSD kinta eksponentiškai (Davies et al., 1972) ir 3-5 min pasiekia pastovią būklę (Astrand, Rodahl, 1986). Isidirbimo metu dèl simpatinio poveikio suaktyvejjimo ir parasimpatinio poveikio išnykimo ŠSD dideja, o atsigavimo metu priešingai - mažèja (Perini et al., 1989; Pierpoint et al., 2000). Svarbią reikšmę ŠSD kaitai taip pat turi hormoniniai ir vidiniai mechanizmai, ypač didelio intensyvumo darbo metu (Wallin et al., 1987). ŠSD kaitos reikšmès krūvio pradžioje ir atsigaunant priklauso nuo darbo intensyvumo, katecholaminu kiekio kraujyje (Orizio et al., 1988; Perini et al., 1989).

Tyrimo tikslas - nustatyti įvairaus intensyvumo aerobinio prieškrūvio poveiki ŠSD kaitai atliekant kartotinį nuosekliai didinamą krūvị (KDK) veloergometru.

\section{TYRIMO METODIKA IR KONTINGENTAS}

Tiriamieji. Sutiko būti tiriami aštuoni sveiki, nerūkantys, fiziškai aktyvūs studentai. Jų vidutinis amžius - 22,5 (2,6) m., ūgis - 1,8 $(0,3) \mathrm{m}$, svoris $-69,6(9,8) \mathrm{kg}$. Tiriamieji tris keturis kartus (po $2-3 \mathrm{~h}$ ) per savaitę kultivavo i̇vairią fizinę veiklą. Testavimo išvakarèse buvo prašoma, kad tiriamieji neatliktu sunkaus fizinio krūvio, o testavimo dieną būtų visiškai nesimankštinę ir pavalgę mažiausiai dvi valandas prieš tyrimus. Skirtingų testavimų atlikimo laikas buvo derinamas, kad visada vyktų tuo pačiu paros metu (dažniausiai ryte) ir tarp testavimų buvo ne mažesnè kaip dviejų dienu pertrauka.

Tyrimams atlikti buvo taikomi tokie metodai:

Pulsometrija. Viso tyrimo metu širdies susitraukimų dažnis $5 \mathrm{~s}$ intervalais buvo registruoja- mas pulso matuokliu „Polar S810“ (Suomija) ir toliau analizuojamas taikant „Microsoft Excel“ programą.

Biocheminė kraujo analizè. Norint nustatyti laktato koncentraciją kraujyje, kapiliarinio kraujo mèginiai iš rankos piršto buvo imami prieš kiekvieną tyrimą, tiriamajam esant ramybès būsenos, taip pat jam atliekant 30 min vidutinio arba didelio intensyvumo aerobinị krūvị 5-ą, 10 -ą, 20-ą ir 30-ą min. Laktato koncentracija kraujyje buvo nustatoma naudojant modifikuotą analizatoriu ,Eksan-G“ (Kulis et al., 1988), kuriame iqmontuota membrana su fermentu laktato oksidaze, galinčiu nustatyti nuo 0,8 iki $25,0 \mathrm{mmol} / 1$ laktato koncentraciją kraujyje.

Kartotinio nuosekliai didinamo krūvio testas (KDK). Kartotini nuosekliai didinamą krūvi tiriamieji atliko „Monark 834E“ (Švedija) veloergometru, kai buvo palaikomas pastovus mynimo dažnumas $70 \mathrm{k}$. / min. Pirmo krūvio dydis $-50 \mathrm{~W}$ ir toliau didinamas po $25 \mathrm{~W}$. Krūvio trukmè -3 min. Po kiekvieno krūvio tiriamasis 3 min pasyviai ilsejjosi sèdėdamas ant veloergometro. Viso testo metu buvo registruojamas ŠSD, o testas nutraukiamas tada, kai tiriamojo ŠSD pasiekdavo $80 \%$ maksimalaus, apskaičiuoto pagal tiriamojo amžių (220 - amžius).

Vidutinio arba didelio intensyvumo aerobinis prieškrūvis (VAP ir DAP). Tiriamasis 30 min vidutinio arba didelio intensyvumo aerobinị krūvị atliko „Monark 834E“ (Švedija) veloergometru, palaikomas pastovus mynimo dažnumas -70 k. / min. Kiekvieno tiriamojo vidutinio ir didelio intensyvumo krūviai buvo apskaičiuojami individualiai pagal jo pasiektą krūvị laktato slenksčio ribose. Laktato slenkstis nustatytas pagal absoliučias ŠSD reikšmes atsigavimo metu atliekant KDK testą (Stasiulis, 1997). Taigi vidutinio intensyvumo krūvis buvo $25 \mathrm{~W}$ mažesnis už LaS, o didelio intensyvumo $-25 \mathrm{~W}$ didesnis už LaS.

ŠSD kaitos analizè. Norint ịvertinti ŠSD kaitą darbo ir atsigavimo metu, šio rodiklio dydžiai (amplitude ir laiko konstanta) „Microcal Origin“ programa buvo analizuojami taikant monoeksponentinę lygti:

$$
\breve{S S D}(\mathrm{t})=\breve{S} S D(b) \pm A \cdot\left(1-\mathrm{e}^{-\mathrm{t} / \tau}\right),
$$

čia ŠSD (b) - ŠSD vidutinė pradinè reikšmė per paskutines 30 darbo arba poilsio sekundžių; A - amplitudè (tv. / min), rodanti ŠSD reikšmès pokyčio dydi; $\tau$ - laiko konstanta (s), nusakanti ŠSD reikšmès pokyčio greitį; $\mathrm{t}$ - trukmė (s) nuo darbo arba poilsio intervalo pradžios. 
Tyrimo organizavimas. Pradžioje kiekvienas tiriamasis atliko kartotinį nuosekliai didinamą krūvi, po kurio atsigavimo metu netiesioginiu būdu pagal ŠSD reikšmes buvo nustatytas individualus LaS (Stasiulis, 1997). Toliau, norint nustatyti vidutinio arba didelio intensyvumo aerobinio prieškrūvio poveikį ŠSD kaitai, kiekvienam tiriamajam buvo parenkamas vidutinio ir didelio intensyvumo krūvis. Antrą ir trečią kartą atvykę i laboratoriją tiriamieji pirmiausia atlikdavo 30 min vidutinio arba didelio intensyvumo aerobini prieškrūvị ir pailseję 5 min vèl pakartodavo KDK testą. Tarp testavimu buvo daromos ne mažesnès kaip dvieju dienu pertraukos ir testai atliekami atsitiktine tvarka.

Matematinė statistika. Apskaičiuoti analizuojamų rodiklių aritmetiniai vidurkiai ir standartiniai nuokrypiai. Ar duomenu skirstinys atitinka normaluji, nustatyta taikant Kolmogorovo-Smirnovo testą. ŠSD kaitos rodiklių vidurkiai skirtingomis testavimo salygomis palyginti taikant neparametrini Wilcoxon testa priklausomoms imtims. Statistinių hipoteziu patikimumui ivertinti pasirinktas reikšmingumo lygmuo, kai $\mathrm{p}<0,05$. Duomenu skaičiavimams atlikti naudotos kompiuterinès programos „Polar Precision Performance“, „Microsoft Excel“, „STATISTICA for Windows“.

\section{REZULTATAI}

Nustatyta, kad tiriamujų laktato koncentracijos kraujyje (La) vidutinès reikšmès atliekant 30 min vidutinio intensyvumo aerobini prieškrūvi (VAP) po pradinio padidejjimo 5-ą darbo minutę ( $\mathrm{p}<0,05$; 1 pav.), vèliau viso krūvio metu mažejo ir darbo pabaigoje buvo nepakitusi $(\mathrm{p}>0,05)$. Didelio

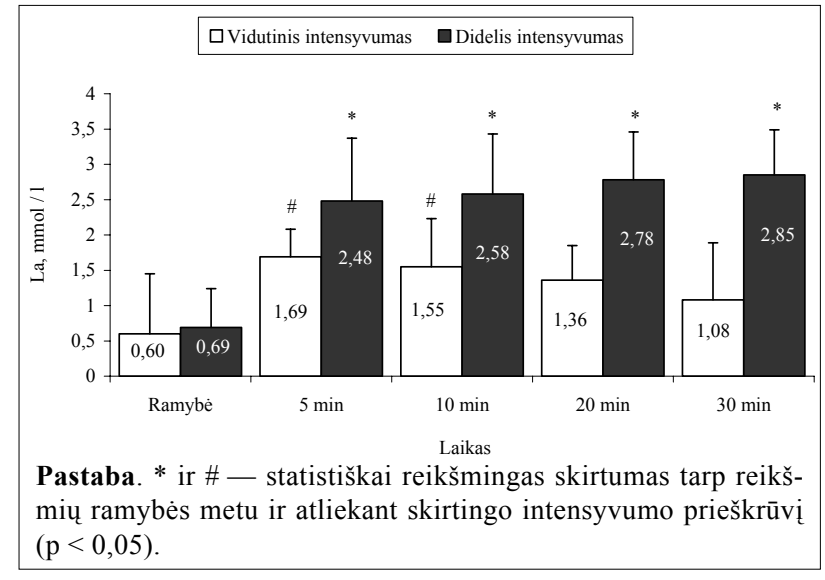

1 pav. Tiriamųjų laktato koncentracijos kraujyje vidutinès reikšmès atliekant 30 min trukmès vidutinio ir didelio intensyvumo aerobinị prieškrūvị

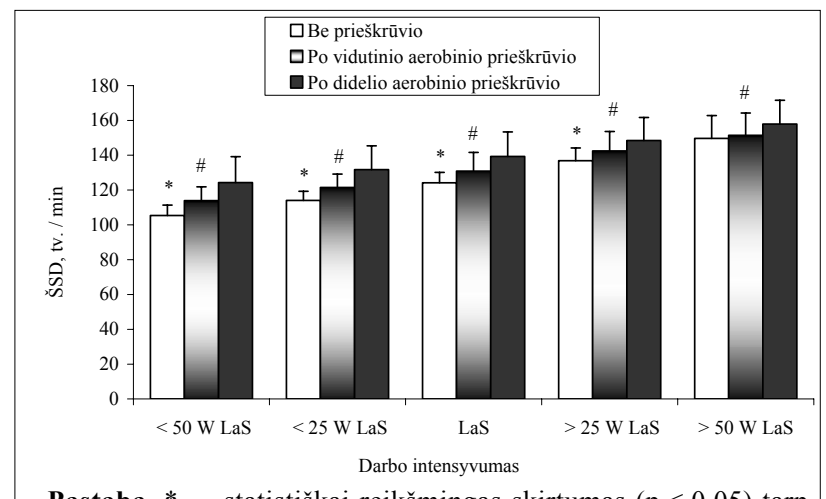

Pastaba. * - statistiškai reikšmingas skirtumas $(\mathrm{p}<0,05)$ tarp reikšmių atliekant testą be prieškrūvio ir po vidutinio aerobinio prieškrūvio; \#- statistiškai reikšmingas skirtumas $(\mathrm{p}<0,05)$ tarp reikšmių atliekant testą be prieškrūvio ir po didelio aerobinio prieškrūvio; - krūvis, kai intensyvumas lygus laktato slenksčiui; $<25 \mathrm{~W} \mathrm{LaS}$ ir $<50 \mathrm{~W} \mathrm{LaS} \mathrm{-} \mathrm{krūviai,} \mathrm{kai} \mathrm{intensyvumas} \mathrm{mažesnis}$ už laktato slenkstị; > $25 \mathrm{~W}$ LaS ir $>50 \mathrm{~W} \mathrm{LaS}$ - krūviai, kai intensyvumas didesnis už laktato slenkstị.

2 pav. ŠSD trečios darbo minutès pabaigoje atliekant KDK testą skirtingomis testavimo sąlygomis

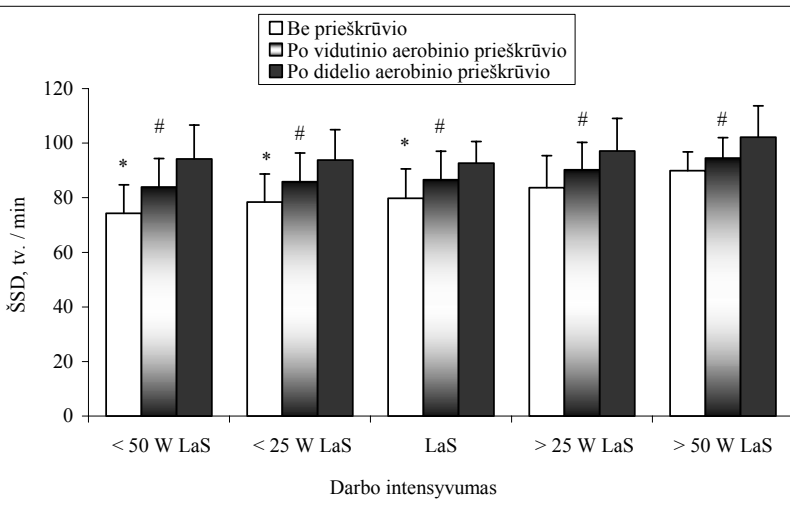

Pastaba. * — statistiškai reikšmingas skirtumas $(p<0,05)$ tarp reikšmių atliekant testą be prieškrūvio ir po vidutinio aerobinio prieškrūvio; \# - statistiškai reikšmingas skirtumas $(p<0,05)$ tarp reikšmių atliekant testą be prieškrūvio ir po didelio aerobinio prieškrūvio; LaS - krūvis, kai intensyvumas lygus laktato slenksčiui; < $25 \mathrm{~W}$ LaS ir $<50 \mathrm{~W} \mathrm{LaS} \mathrm{-} \mathrm{krūviai,} \mathrm{kai} \mathrm{intensyvumas} \mathrm{ma-}$ žesnis už laktato slenkstị; > $25 \mathrm{~W} \mathrm{LaS} \mathrm{ir} \mathrm{>} \mathrm{50} \mathrm{W} \mathrm{LaS} \mathrm{-} \mathrm{krūviai,}$ kai intensyvumas didesnis už laktato slenksti.

3 pav. ŠSD ketvirtą atsigavimo minutę atliekant KDK testą skirtingomis testavimo sąlygomis

intensyvumo aerobinio prieškrūvio (DAP) pradžioje La taip pat reikšmingai padidèjo (5-ą min; $\mathrm{p}<0,05)$ ir iki darbo pabaigos šiek tiek didejo. Todèl atlikus 30 min DAP laktato koncentracija kraujyje buvo reikšmingai didesnė $(\mathrm{p}<0,05)$, nei atlikus VAP.

Neparametriniu Wilcoxon metodu nustatyta, kad atliekant KDK testą po VAP absoliučios ŠSD reikšmès trečios krūvio minutès pabaigoje reikšmingai padidejo visais darbo intensyvumo atvejais ( $<<0,05 ; 2$ pav.), išskyrus tada, kai jis buvo $50 \mathrm{~W}$ didesnis už LaS $(\mathrm{p}<0,05)$. Po DAP šis rodiklis išliko reikšmingai didesnis viso kartotinio nuosekliai didinamo krūvio metu ( $\mathrm{p}<0,05 ; 2$ pav.). 
Lentelè. ŠSD kaitos monoeksponentinio trendo rodiklių vidurkiai atliekant KDK testą be skirtingo intensyvumo aerobinio prieškrūvio ir po jo

\begin{tabular}{|c|c|c|c|c|c|c|c|}
\hline \multirow{2}{*}{ Rodikliai } & \multirow{2}{*}{ Krūvis } & \multicolumn{3}{|l|}{ Isidirbimas } & \multicolumn{3}{|l|}{ Atsigavimas } \\
\hline & & Be prieškrūvio & Po VAP & Po DAP & Be prieškrūvio & Po VAP & Po DAP \\
\hline \multirow{5}{*}{$\begin{array}{l}\text { Amplitude, } \\
\text { tv. / min }\end{array}$} & $<50 \mathrm{~W} \mathrm{LaS}$ & $27,2(12,7)$ & $29,1(13,1)$ & $28,2(13,8)$ & $31,7(11,5)$ & $30,2(13,7)$ & $31,6(12,4)$ \\
\hline & $<25 \mathrm{~W} \mathrm{LaS}$ & $37,2(13,4)$ & $36,0(10,7)$ & $34,6(13,2)$ & $37,8(11,1)$ & $35,6(13,4)$ & $39,7(10,4)$ \\
\hline & LaS & $46,8(15,3)$ & $45,0(13,9)$ & $45,8(10,9)$ & $48,2(12,5)$ & $45,4(13,6)$ & $47,6(13,6)$ \\
\hline & $>25 \mathrm{~W} \mathrm{LaS}$ & $56,1(14,1)$ & $55,2(12,9)$ & $55,4(12,5)$ & $58,3(12,9)$ & $55,1(12,8)$ & $55,1(16,9)$ \\
\hline & $>50 \mathrm{~W} \mathrm{LaS}$ & $63,4(13,4)$ & $57,9(8,3)$ & $59,1(10,2)$ & $60,8(9,3)$ & $58,4(8,9)$ & $58,3(11,2)$ \\
\hline \multirow{5}{*}{$\begin{array}{l}\text { Laiko kon- } \\
\text { stanta, s }\end{array}$} & $<50 \mathrm{~W} \mathrm{LaS}$ & $18,3(10,6)$ & $16,3(4,3)$ & $21,3(8,6)$ & $22,3(6,9)$ & $31,1(10,4)$ & $38,5(18,1)$ \\
\hline & $<25 \mathrm{~W} \mathrm{LaS}$ & $21,2(13,9)$ & $17,1(10,0)$ & $29,6(13,2)$ & $26,1(9,1)$ & $24,0(11,5)$ & $33,4(19,0)$ \\
\hline & LaS & $31,0(16,5)$ & $26,3(13,1)$ & $32,0(12,6)$ & $30,0(12,7)$ & $31,3(9,3)$ & $38,6(14,5)$ \\
\hline & $>25 \mathrm{~W} \mathrm{LaS}$ & $26,2(12,0)$ & $26,8(10,2)$ & $31,0(11,5)$ & $31,2(10,3)$ & $30,2(5,1)$ & $42,2(18,1)$ \\
\hline & $>50 \mathrm{~W} \mathrm{LaS}$ & $38,5(13,2)$ & $32,8(12,4)$ & $32,4(5,4)$ & $41,9(6,1)$ & $40,6(10,3)$ & $48,7(11,8)$ \\
\hline
\end{tabular}

Pastaba. Skliausteliuose pateikti rodiklių standartiniai nuokrypiai. LaS - krūvis, kai intensyvumas lygus laktato slenksčiui; < 25 W LaS ir $<50 \mathrm{~W}$ LaS - krūviai, kai intensyvumas mažesnis už laktato slenkstị; > $25 \mathrm{~W}$ LaS ir > $50 \mathrm{~W}$ LaS — krūviai, kai intensyvumas didesnis už laktato slenkstị; VAP — vidutinio intensyvumo aerobinis prieškrūvis; DAP — didelio intensyvumo aerobinis prieškrūvis.

Kiekvieno atsigavimo ketvirtą minutę absoliučios ŠSD reikšmès po VAP nustatytos reikšmingai didesnès ( $\mathrm{p}<0,05 ; 3$ pav.), kai darbo intensyvumas buvo mažesnis arba lygus LaS. Visgi po DAP šis rodiklis reikšmingai padidejo visais intensyvumo atvejais ( $p<0,05 ; 3$ pav.).

ŠSD kaitos monoeksponentinio trendo rodikliu analizè rodo, kad atliekant KDK testą skirtingomis testavimo sąlygomis nei po VAP, nei po DAP ŠSD kaitos rodikliai (amplitude ir laiko konstanta) nepakito $(\mathrm{p}>0,05)$ (̌rr. lent.).

\section{REZULTATŲ APTARIMAS}

Tyrimu nustatyta, kad ir lengvesnis, ir sunkesnis už laktato slenksti (atitinkamai vidutinio ir didelio intensyvumo) 30 min aerobinis prieškrūvis paveike absoliučias ŠSD reikšmes tiriamajam atliekant kartotini ( 3 min darbo ir 4 min poilsio) nuosekliai didinamą krūvị. Viso testo metu nepastebèta nei lengvesnio, nei sunkesnio aerobinio prieškrūvio poveikio ŠSD kaitos santykiniam greičiui ir pokyčio dydžiui.

Senokai pastebėta, kad ŠSD darbo pradžioje kinta eksponentiškai ir per maždaug $3-5 \mathrm{~min}$ pasiekia pastovią būklę (Astrand, Rodahl, 1986). Tačiau dirbant skirtingo intensyvumo darbą ŠSD kaita gali skirtis. Kai dirbama vidutiniu intensyvumu (iki LaS), ŠSD kaita yra monoeksponentinè (Orizio et al., 1983). Dirbant didesniu intensyvumu už LaS, pastebètas bieksponentinis ŠSD kitimas, kuriam esant galima išskirti greituosius ir lètuosius komponentus (Linnarson, 1974). Žinodami, kad ŠSD kaitos greitoji fazè pasireiškia per pirmas darbo minutes, o lètoji prasideda tik nuo trečios ar ketvirtos (tiriamieji atliko tik 3 min trukmès krūvius), ŠSD kaitą analizavome taikydami monoeksponentinio trendo lygti.

K. E. Sietsema ir kt. (1989) nustatè reikšmingą ryši tarp ŠSD kaitos įsidirbimo fazeje ir darbo intensyvumo. K. Baum ir kt. (1992) teige, kad ŠSD kaitos laiko konstanta pirmoje ir antroje isidirbimo fazeje nepriklauso nuo intensyvumo. Mūsų duomenimis, nuosekliai didejant darbo intensyvumui, ŠSD kaitos monoeksponentinio trendo rodikliai (laiko konstanta ir pokyčio amplitudè) reikšmingai didejo. Šis prieštaravimas gali atsirasti dèl skirtingų matematinès analizès būdų taikymo. Be to, analizavome krūvius, artimesnius LaS. Kaip nustate daugelis mokslininkų, šis slenkstis pasireiškia tada, kai darbo intensyvumas siekia apie 40-60\% (Skinner, McLellan, 1980). Taigi, atliekant ši tyrimą, kai kurių krūvių metu buvo viršyta ta riba, iki kurios ŠSD dideja monofaziškai.

Manoma, kad fizinio darbo pradžioje ŠSD reguliuoja neurogeniniai veiksniai, kurių esmè komandos iš nervinių centrų ir raumenų refleksai (Mitchell et al., 1983). Pastarajame dalyvauja III ir IV tipo nervinès skaidulos, atitinkamai reaguojančios į mechanini poveikị ir cheminius pokyčius raumenyse (Rybichi et al., 1985). Eferentinę šiu refleksų dali sudaro parasimpatinès ir simpatinès širdị inervuojančios skaidulos. Greitą ŠSD kitimą lengvo darbo pradžioje kaip tik gali lemti centrinès nervu sistemos komandos ir III tipo nerviniu skaidulų aktyvumas. Parasimpatinio aktyvumo išnykimas darbo pradžioje taip pat sukelia greitą ŠSD didejjimą (apie 30 tv. / min) (Robinson et al., 
1966). Kaip teigia B. C. Maciel ir kt. (1986), parasimpatinès nervų sistemos blokada reikšmingai sulètina ŠSD kitimą pačioje i̇sidirbimo pradžioje, o simpatinès nervų sistemos blokada paveikia tik lètosios fazès kaitą, ypač dirbant didesniu intensyvumu. Esant didesniam intensyvumui, ŠSD reguliuoja kraujo katecholaminai, padideja simpatinis poveikis ir širdies ritmo vedlio skaidulu temperatūra (Wallin et al., 1987). D. A. Schneider ir kt. (2002) nustaté, kad ŠSD kaitos laiko konstanta, dirbant kojomis ir rankomis krūvio pradžioje, kol ŠSD pasiekia 100 tv. / min, nesiskiria. Tai rodo, kad vienodu intensyvumu dirbant ir rankomis, ir kojomis nervo klajoklio slopinimo greitis nesiskiria. Tačiau atliekant darbą rankomis dèl mažesnès simpatinès širdies stimuliacijos ŠSD kaita lètesnè, negu dirbant kojomis. G. K. Savard ir kt. (1989) irodè, kad plazmos noradrenalino koncentracijos padidejjimas fizinio darbo metu yra susijęs su dirbančių raumenų mase. Taikytų krūvių metu ŠSD kaitos amplitude visada buvo didesnè nei 30 tv. / min, todèl ŠSD kaita galëjo paveikti ir nerviniai, ir humoraliniai bei vidiniai organizmo mechanizmai. Tą rodo užfiksuotos didelès laiko konstantos reikšmès.

Neaptikta darbų, kuriuose būtų analizuojamas VAP ir DAP poveikis ŠSD kaitai atliekant skirtingo intensyvumo krūvi. Kur kas daugiau tyrinètas tokių prieškrūviu poveikis deguonies suvartojimo $\left(\dot{\mathrm{VO}}_{2}\right)$ kaitai. Nustatyta, kad vidutinio intensyvumo prieškrūvis nepagreitina $\dot{\mathrm{VO}}_{2}$ kaitos nei vidutinio, nei didelio intensyvumo darbo pradžioje. Be to, nei vidutinio, nei didelio intensyvumo prieškrūvis neveikia minètos kaitos atliekant vidutinio intensyvumo krūvi (Gerbino et al., 1996). Tai leidžia iš dalies paaiškinti, kodèl tyrimo metu po vidutinio intensyvumo aerobinio prieškrūvio nepakito ŠSD kaita dirbant nei didesniu, nei mažesniu už LaS intensyvumu - nepakitęs deguonies suvartojimas nereikalavo didesnio deguonies pernašos sistemu aktyvumo.
Nustatyta, kad absoliučios ŠSD reikšmès issidirbimo ir atsigavimo pabaigoje buvo padidejusios, ypač po sunkesnio prieškrūvio. Negalima atmesti galimybès, kad atliekant nuosekliai didinamo krūvio testą po prieškrūvio laktato susidarymo procesai galejo prasidèti anksčiau dèl padidejusios katecholaminu (Vincent et al., 2004) ir piruvato koncentracijos atsigavimo metu po sunkaus darbo, taip pat dèl ankstyvesnio greitujų motorinių vienetų rekrutavimo (Tegtbur et al., 1993). Irodyta, kad po intensyvaus darbo ŠSD eksponentiškai mažeja iki tokio lygio, kuris yra aukštesnis, negu buvęs prieš fizini krūvị. Tai priklauso nuo krūvio intensyvumo ir trukmès. Po sunkesnio ir ilgesnio fizinio krūvio reikia daugiau laiko atsigauti (Perini et al., 1989; Baum et al., 1992). Visgi lètojo ŠSD atsigavimo mechanizmai yra neaiškūs. Žinoma, kad vykstant acidozès procesams, kai atliekamas nuosekliai didinamo krūvio testas, laktato koncentracijos kreivei būdinga „U“ raidès forma (Davis, Gass, 1981). Lengvo krūvio metu vyrauja laktato likvidavimo procesai, o viršijus laktato pastoviosios būklès slenkstį - laktato susidarymo procesai. Kadangi po DAP laktato koncentracija buvo reikšmingai padidejusi dar prieš testą ir ŠSD padidejimas pastebimas dirbant įvairiu intensyvumu, tai galèjo turèti įtakos ŠSD reikšmingam padidejjimui atsigavimo pabaigoje, ypač lengvesnių krūvių metu.

\section{IŠVADA}

Ir lengvesnis, ir sunkesnis už laktato slenksti (atitinkamai, vidutinio ir didelio intensyvumo) 30 min trukmès aerobinis prieškrūvis veikia absoliučias ŠSD reikšmes (jas padidina), bet nepaveikia ŠSD kaitos santykinio greičio ir pokyčio dydžio atliekant kartotini ( $3 \mathrm{~min}$ darbo ir $4 \mathrm{~min}$ poilsio) nuosekliai didinamą krūvị.

\section{LITERATŪRA}

Astrand, P. O., Rodahl, K. (1986). Textbook of Work Physiology. New York: McGraw-Hill. P. 299, 359-360.

Baum, K., Eßfeld, D., Leyk, D., Stegemann, J. (1992). Blood pressure and heart rate during rest-exercise and exercise-rest transitions. European Journal of Applied Physiology, 64, 134-138.

Davies, C. T. M., di Prampero, P. E., Cerretelli, P. (1972). Kinetics of cardiac output and respiratory gas exchange during exercise and recovery. Journal of Applied Physiology, 32, 618-625.
Davis, H. A., Gass, G. C. (1981). The anaerobic threshold as determined before and during lactic acidosis. European Journal of Applied Physiology, 47, 141-149.

Gerbino, A., Ward, S. A., Whipp, B. J. (1996). Effects of prior exercise on pulmonary gas-exchange kinetics during high-intensity exercise in humans. Journal of Applied Physiology, 80, 99-107.

Grassi, B. (2001). Regulation of oxygen consumption at the onset of exercise. Is it really controversial? Exercise and Sports Science Review, 29, 134-138. 
Jones, A., Carter, H. (2000). The effect of endurance training on parameters of aerobic fitness. Sports Medicine, 29, 373-386.

Kulis, Y. Y., Laurinavichyus, V. S. A., Firantas, S. G. A. et al. (1988). Determination of lactic acid with an Exan-G analyser. Journal of Analytic Chemistry of USSR, 43 (7), $1521-1523$.

Linnarsson, D. (1974). Dynamics of pulmonary gas exchange and heart rate changes at start and of exercise. Acta Physiologica Scandinavica (Suppl.), 415, 1-68.

Maciel, B. C., Gallo, L. Jr., Neto, J. A., Filho, E. C., Martins, L. E. (1986). Autonomic nervous control of the heart rate during dynamic exercise in normal man. Clinical Science, 4, 457-460.

Mitchell, J. H., Kaufman, M. L., Iwamoto, G. A. (1983). The exercise pressor reflex: Its cardiovascular effects, afferent mechanism, and central pathways. Annual Review of Physiology, 45, 229-242.

Orizio, C., Comande, S., Margonato, V., Veicsteinas, V. (1983). Kinetics of heart rate increase with exercise in different athletes. IRCS Medical Science, 11, 329-330.

Orizio, C., Perini, R., Comande, A. et al. (1988). Plasma catecholamines and heart rate at the beginning of muscular exercise in man. European Journal of Applied Physiology, 57, 644-651.

Perini, R., Orizio, C., Comande, A. et al. (1989). Plasma norepinephrine and heart rate dynamics during recovery from submaximal exercise in men. European Journal of Applied Physiology, 58, 879-883.

Pierpoint, M. D., Stolpman, M. D., Gornick, M. D. (2000). Heart rate recovery post-exercise as an index of parasympathetic activity. Journal of the Autonomous Nervous System, 80, 169-174.

Robinson, B. F., Epstein, S. E., Beiser, G. D., Braunwald, E. (1966). Control of heart rate by the autonomic nervous system. Circulatory Research, 19, 400-411.

Rybichi, K. J., Waldrop, T. G., Kaufman, M. P. (1985).
Increasing gracilis muscle interstitial potassium concentrations stimulate group III and IV afferents. Journal of Applied Physiology, 58, 936-941.

Savard, G. K., Richter, E. A., Strange, S. et al. (1989). Norepinephrine spillover from skeletal muscle during exercise in humans: Role of muscle mass. American Journal of Physiology, 256 (6), 1812-1818.

Schneider, D. A., Wing, A. N., Morris, N. R. (2002). Oxygen uptake and heart rate kinetics during heavy exercise: A comparison between arm cranking and leg cycling. European Journal of Applied Physiology, 88, 100-106.

Sietsema, K. E., Daly, J. A., Wasserman, K. (1989). Early dynamics of $\mathrm{O}_{2}$ uptake and heart rate as affected by exercise work rate. Journal of Applied Physiology, 67 (6), $2535-2541$.

Skinner, J. S., McLellan, H. (1980). The transition from aerobic to anaerobic metabolism. Research Quarterly of Exercise and Sports, 51 (1), 234-248.

Stasiulis, A. (1997). The relationship between heart rate recovery level and lactate threshold during intermittent exercise. Pflügers Archiv. European Journal of Applied Physiology, 433, 131.

Tegtbur, U., Busse, M. W., Braumann, K. M. (1993). Estimation of an individual equilibrium between lactate production and catabolism during exercise. Medicine and Science in Sports and Exercise, 25, 620-627.

Tschakovsky, M. E., Hughson, R. L. (1999). Interaction of factors determining oxygen uptake at the onset of exercise. Journal of Applied Physiology, 86 (4), 1101-1113.

Vincent, S., Berthon, P., Zouhal, H. et al. (2004). Plasma glucose, insulin and catecholamine responses to a Wingate test in physically active women and men. European Journal of Applied Physiology, 91, 15-21.

Wallin, B., Morlin, C., Hjiemdahl, P. (1987). Muscle sympathetic activity and venous plasma noradrenaline concentracions during static exercise in normotensive and hypertensive subjects. Acta Physiologica Scandinavica, $129,489-497$.

\title{
INFLUENCE OF PRIOR AEROBIC EXERCISE OF DIFFERENT INTENSITY ON HEART RATE KINETICS DURING INTERMITTENT INCREASING CYCLING EXERCISE
}

\author{
Loreta Dubininkaitė, Arvydas Stasiulis, Neringa Baranauskienė \\ Lithuanian Academy of Physical Education, Kaunas, Lithuania
}

\begin{abstract}
This study was aimed to determine the influence of prior aerobic exercise of different intensity on heart rate (HR) kinetics during intermittent increasing cycling exercise (ICE). Eight healthy, non-smoking, physically active male students (age $-22.5(2.6)$ years, height $-1.8(0.3) \mathrm{m}$, weight $-69.6(9.8) \mathrm{kg})$ volunteered to participate in the study. Each subject was tested three times on separate days. During the first visit the ICE was performed on the mechanically braked cycle ergometer (Monark 834E, MonarkCrescent $\mathrm{AB}$, Sweden) and the pedaling rate was $70 \mathrm{rpm}$. The test consisted of 3 min repeated work and 4 min passive rest intervals. No special warm-up was performed. The work rate of the first work period was
\end{abstract}


set to $50 \mathrm{~W}$. Thereafter the intensity was increased by $25 \mathrm{~W}$ during each consecutive work period. The HR was continuously monitored and recorded using short-range telemetry "Polar S810" (Finland). The ICE test was continued until the subjects' HR achieved over $80 \%$ age predicted HR maximum. The lactate threshold (LT) was estimated by indirect method using absolute values of HR at recovery period during ICE (Stasiulis, 1997). During the second and third visits the subjects randomly performed moderate exercise ( $25 \mathrm{~W}$ below LT) (ME) or heavy exercise ( $25 \mathrm{~W}$ above LT) (HE) for $30 \mathrm{~min}$ and after $5 \mathrm{~min}$ of rest repeated ICE protocol. At rest, at $5^{\text {th }}, 10^{\text {th }}, 20^{\text {th }}$ and $30^{\text {th }}$ min of ME or HE fingertip blood samples were collected into capillary tubes and subsequently analyzed for blood lactate concentration as described previously (Kulis et al., 1988). Lactate concentration in the blood was established by means of Eksan-G analyzer using a membrane with enzyme lactaoxidase. The HR during on- and off-transitions were assessed by fitting mono-expotential function. Comparisons of parameters between different testing conditions were conducted using Wilcoxon nonparametrics matched pairs test.

After $30 \mathrm{~min}$ of HE the blood lactate concentration was significantly increased by $2.85(0.64) \mathrm{mM}$ $(\mathrm{P}<0.05)$ but remained unchanged after ME of the same duration $(1.08(0.81) \mathrm{mM} ; \mathrm{P}>0.05)$. The mean values of HR during $3^{\text {rd }}$ min of work periods were significantly increased after both ME and HE. This increase tended to be higher after prior HE. After prior HE the mean values of HR during $4^{\text {th }}$ min of recovery were significantly increased at all intensities while after prior ME they were higher only at intensities equal to or below LT. Neither prior moderate nor heavy aerobic exercises had effect on the HR on- and off-kinetics parameters (amplitude and time constant $)(\mathrm{P}>0.05)$.

It was concluded that the prior both light and heavy aerobic exercise had influence on the absolute values of HR during intermittent increasing cycling exercise without any effect on HR on- and off-kinetics.

Keywords: heart rate, prior load, blood lactate, cycling.

Gauta $2007 \mathrm{~m}$. vasario $12 \mathrm{~d}$.

Received on February 12, 2007

\author{
Loreta Dubininkaitè \\ Lietuvos kūno kultūros akademija \\ (Lithuanian Academy of Physical Education) \\ Sporto g. 6, LT-44221 Kaunas \\ Lietuva (Lithuania) \\ Tel +37061691414 \\ E-mail1.dubininkaite@1kka.1t
}

